\title{
Double-stranded DNA measurement in lakes with the fluorescent stain PicoGreen and the application to bacterial bioassays
}

\author{
James B. Cotner*, Megan L. Ogdahl, Bopaiah A. Biddanda \\ Department of Ecology, Evolution and Behavior, University of Minnesota, 1987 Upper Buford Circle, St. Paul, \\ Minnesota 55108, USA
}

\begin{abstract}
We used the double-stranded DNA (dsDNA) stain PicoGreen with a microplate fluorometer to measure bacterial abundance, biomass, and growth rates in lake water. PicoGreen fluorescence units (PFU) correlated closely with bacterial abundance measured with acridine orange direct counts $\left(\mathrm{R}^{2}=0.95\right.$ to 0.98$)$ as well as bacterial biomass inferred from image analysis $\left(\mathrm{R}^{2}=0.95\right.$ to 0.98) in eutrophic waters. PicoGreen fluorescence increased proportionally with bacterial size, indicating that it was a good indicator of biomass as well as abundance. In oligotrophic Lake Superior, there was a weaker, but significant $(\mathrm{p}<0.05)$ correlation between PFU and abundance $\left(\mathrm{R}^{2}=0.52\right)$ as well as PFU and biomass $\left(\mathrm{R}^{2}=0.54\right)$. Growth rate measurements in bottle cultures showed a similar relationship, with PFU, abundance, and biomass being more tightly correlated in productive waters than in oligotrophic waters. Parallel dilution cultures were performed in microplate wells (nanocosms) and 11 bottles. The slope of nanocosm fluorescence to bottle fluorescence was ca 1 , indicating that nanocosms mimicked bacterial abundance and growth in bottle cultures. Preservation of Escherichia coli with formaldehyde showed that there was an initial loss of dsDNA of about 10 to $15 \%$ with little subsequent loss for $2 \mathrm{wk}$, indicating that bacteria from growth experiments conducted in the field could be preserved for subsequent analysis in the laboratory. Bacterial cellular dsDNA content in 3 Minnesota lakes varied between 0.6 and $6.2 \mathrm{fg} \mathrm{cell}^{-1}$ and was highest in the most eutrophic and most rapidly growing bacterial community, i.e., the more eutrophic lakes. These results suggest that the PicoGreen method is effective for growth bioassays in systems with moderate to high levels of bacterial productivity. PicoGreen coupled with a microplate fluorescence reader is a promising method for determining bacterial biomass and growth rates, especially in meso- to eutrophic systems.
\end{abstract}

KEY WORDS: dsDNA $\cdot$ Bioassay $\cdot$ Bacterial growth rate $\cdot$ PicoGreen $\cdot$ Biomass $\cdot$ Abundance

\section{INTRODUCTION}

A central aspect of aquatic microbial ecology is bacterial abundance, distribution, and growth. Epifluorescence microscopy is one of the major tools that enabled quantification of bacterial abundance (Hobbie et al. 1977), and radioisotopes (primarily ${ }^{3} \mathrm{H}$-thymidine [Fuhrman \& Azam 1982] and ${ }^{3} \mathrm{H}$-leucine [Kirchman et

*E-mail: cotne002@umn.edu al. 1985]) enabled measurement of bacterial productivity. Counting bacteria with epifluorescence microscopy is a tedious but necessary step of data collection, and radioisotope methods can be problematic because of increasing difficulty obtaining permits to use isotopes at field stations or on ships.

Fluorometry in conjunction with the use of new fluorescent stains provides tools for alleviating some of these problems. Flow cytometry is being increasingly used in aquatic microbiology to measure picoplankton abundance and biomass (Yentsch et al. 1983, Button \& 
Robertson 1993, Moreiraturcq et al. 1993, Porter et al. 1995), but these instruments are expensive and often not available to most researchers. Tranvik (1997) recently used the double-stranded DNA (dsDNA) stain PicoGreen (Molecular Probes Inc., Eugene, OR, USA) in combination with a fluorometer to measure bacterial abundance in lake water and seawater. Unlike DAPI and acridine orange, PicoGreen can be used while the microbes remain suspended in solution because of the high specificity of the dye and the high sensitivity of the assay ( $25 \mathrm{pg}$ dsDNA ml $\mathrm{m}^{-1}$ according to the manufacturer). Furthermore, there is limited interference from RNA and single-stranded DNA that may be present in relatively high concentrations in lake water. In the present study, we showed that PicoGreen can be used with a microplate fluorescence reader to quantify bacterial abundance and biomass and measure growth rates in dilution cultures. Furthermore, this method can easily be used to conduct limiting nutrient bioassays. With the microplate fluorometer, multiple replicates can be analyzed in a matter of minutes. Another advantage is that sample volumes are small $(<0.2 \mathrm{ml})$, minimizing the use of expensive fluorescence reagents.

\section{MATERIALS AND METHODS}

We measured bacterial abundance, biomass, and growth rates in 3 lakes in Minnesota, USA in summer 1999. Lake Owasso is a moderately productive (5 $\mu \mathrm{g}$ chlorophyll $\mathrm{l}^{-1}$ ), shallow (10 m maximum depth) lake and Lake Mitchell is a very eutrophic (>30 $\mu \mathrm{g}$ chlorophyll $\mathrm{l}^{-1}$ ), shallow (6 m maximum depth) lake (Biddanda et al. 2001). Both of these lakes are located within 10 miles of University of Minnesota's Saint Paul Campus. Lake Superior is an extremely large (82 $350 \mathrm{~km}^{2}$, maximum depth $406 \mathrm{~m}$ ), oligotrophic lake (<1 $\mu$ g chlorophyll $\mathrm{l}^{-1}$; El-Shaarawi \& Munawar 1978). Lake Superior samples were collected from the RV 'Blue Heron' Stn F $\left(47^{\circ} 03.9^{\prime} \mathrm{N}, 91^{\circ} 25.8^{\prime} \mathrm{W}\right)$ and Stn G $\left(47^{\circ} 02.9^{\prime} \mathrm{N}, 90^{\circ} 57.3^{\prime} \mathrm{W}\right)$ in the western arm of the lake.

Lake water dilution cultures. We examined bacterial growth by measuring the change in dsDNA with PicoGreen in 11 lake water dilution cultures (Ammerman et al. 1984) in the lakes. Lake water cultures were diluted 1 part $<1.0 \mu \mathrm{m}$ filtered water in 9 parts $<0.2 \mu \mathrm{m}$ filtered water. All size fractionation was done using 1.0 and $0.2 \mu \mathrm{m}$ Nuclepore cartridge filters (Biddanda et al. 2001). Microscopic examination of samples before and after filtration through the $1 \mu \mathrm{m}$ pore-size filter showed that $>95 \%$ of the total bacterial community passed this filter in all of the systems, indicating that we were not removing a significant portion of the initial community (Biddanda et al. 2001). All cultures were incubated in the dark for 48 to $106 \mathrm{~h}$ at ambient temperatures $(26,22$, and $10^{\circ} \mathrm{C}$ for lakes Owasso, Mitchell, and Superior, respectively). Dilution cultures were performed either with no nutrients added (control), with $30 \mu \mathrm{M}$ concentrations of glucose, $5 \mu \mathrm{M}$ ammonium, and $0.5 \mu \mathrm{M}$ phosphate (plus nutrient treatment) added, or with $5 \mathrm{mg} \mathrm{l}^{-1}$ nutrient broth added (plus NB treatment; Difco). No nutrient broth was added to Lake Superior cultures because of the extremely low ambient nutrient concentrations in this lake.

One hundred $\mu \mathrm{l}$ nanocosm cultures were also set up in black 96-well microplates with an ultra-thin clear bottom having a total capacity of $200 \mu$ well $^{-1}$ (Corning Costar). A sub-sample of the 1:9 dilutions prepared above was added to 8 replicate microplate wells and incubated at ambient temperature in the dark, as in the dilution bottle experiments. At the completion of the incubation, PicoGreen reagents were added and fluorescence was measured (see below).

PicoGreen fluorescence measurements. Fresh working stock was made daily by diluting the PicoGreen stock solution obtained from Molecular Probes in TE buffer (10 mM Tris-HCl, 1 mM EDTA, pH 7.5) at a concentration of $1: 200$. One hundred $\mu$ l of sample was pipetted into 96-well microplates. Eight replicates were performed, and an 8-channel micropipettor was used for sample loading. Nanocosms were not sub-sampled because they were incubated as eight $100 \mu \mathrm{l}$ sub-samples already. One hundred $\mu$ l of PicoGreen working stock was added to each well, and the plates were incubated in the dark at room temperature for 2 to $5 \mathrm{~min}$. The samples were then measured in an FL600 Microplate Fluorescence Reader using KC4 software (BIO-TEK) with peak excitation at $480 \mathrm{~nm}$ and peak emission at $520 \mathrm{~nm}$. Fluorescence was measured in arbitrary units, PicoGreen fluorescence units (PFU), or with standard solutions consisting of $\lambda$ DNA (Molecular Probes) in TE buffer diluted with natural water filtered twice with $0.2 \mu \mathrm{m}$ pore-size syringe filters to remove any particulate dsDNA.

We diluted whole lake water and $1 \mu \mathrm{m}$ pre-filtered water with various quantities of particle-free water to examine the percentage contribution of bacterial dsDNA to the total seston DNA. We assumed that most of the particles in the $<1 \mu \mathrm{m}$ size fraction were bacteria. Whole lake water and $<1 \mu \mathrm{m}$ water were diluted with $0,50,70,80,90$, and $100 \% 0.2 \mu \mathrm{m}$ filtered water to generate gradients in particle abundance, and PicoGreen fluorescence was measured as above.

Bacterial abundance, biomass, and growth rates. Bacterial abundance was measured microscopically at intervals throughout the incubation. Bacteria were preserved with formalin ( $2 \%$ final concentration) and slides were prepared within $1 \mathrm{~d}$. Samples were stained with acridine orange or DAPI (Lake Superior), filtered onto $0.2 \mu \mathrm{m}$ black polycarbonate filters, and counted by 


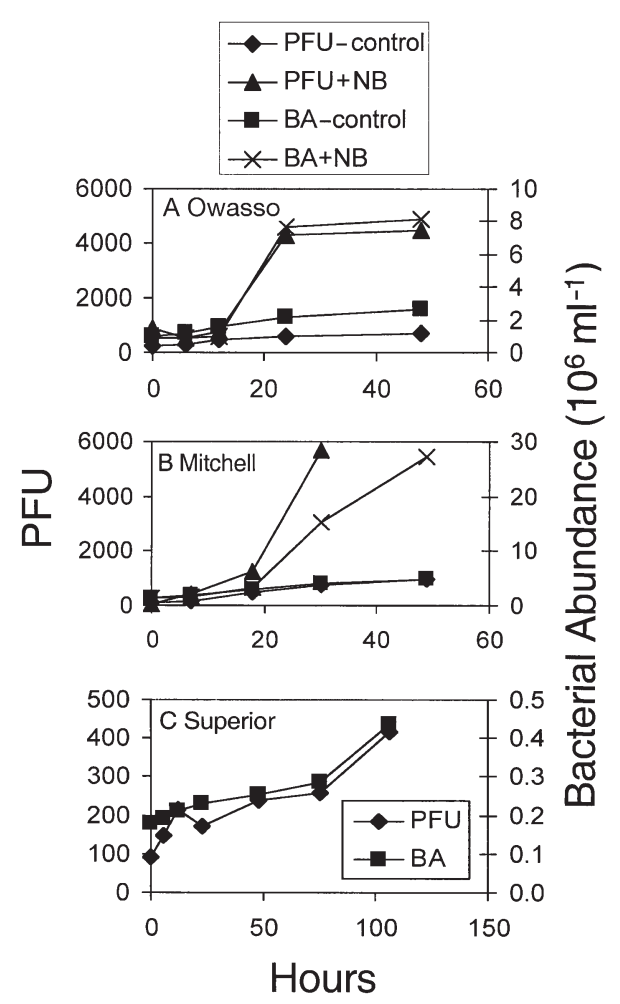

Fig. 1. PicoGreen fluorescence (measured in arbitrary PicoGreen fluorescence units [PFU]) and bacterial abundance (BA) from direct counts (right $y$-axis) over time in individual bioassay incubations in lakes (A) Owasso, (B) Mitchell, and (C) Superior Stn F. Data are shown for control treatments (no nutrients added) and nutrient broth (NB) enrichments for lakes Owasso and Mitchell. In Lake Superior, data from the enrichment cultures (plus glucose, ammonium, and phosphate) are shown because net growth was not observed in the control treatment

epifluorescence microscopy (Hobbie et al. 1977, Porter \& Feig 1980). A minimum of 10 fields were viewed on each filter, and a minimum of 250 bacteria were counted. Growth rate estimates were determined from bacterial abundance, biomass, or PFU, at 2 successive time intervals and the equation: $\left[\ln (B)_{X+1}-\ln (B)_{X}\right] / t$, where $B$ is bacterial abundance or biomass, $x$ and $x+1$ are successive times, and $t$ is the time interval between measurements. We used only the exponential portion of the growth curve, which meant that only 2 to 3 points were typically used in lakes Owasso and Mitchell, but 3 to 5 points could be used in Lake Superior. Bacterial biomass was estimated using epifluorescence microscopy and image analysis. Images were analyzed using a SPOT digital camera with Image Pro Plus software. At least 250 stained bacteria were photographed and sized for each sample. From cell volume, we estimated cell carbon by converting cell volume to dry weight using the formula $D W=435 \times V^{0.86}$, where $D W$ is dry weight in femtograms and $V$ is cell volume in $\mu^{3}$
(Loferer-Krössbacher et al. 1998). We converted $D W$ to carbon by assuming that $50 \%$ of the $D W$ was carbon. All cells were assumed to be ellipsoidal.

Preservation of cells and PicoGreen fluorescence. We examined whether cells for PicoGreen assays could be preserved in formaldehyde before analysis with the microplate reader. Escherichia coli was grown in a minimal glucose medium, with 3-(N-morpholino)propanesulfonic acid (MOPS; Sigma, $40 \mathrm{mM}$ ) buffer, to an exponentially growing population. The medium contains glucose and potassium phosphate at concentrations of 309 and $5.80 \mathrm{mM}$, respectively. Escherichia coli was preserved with $2 \%$ formaldehyde, and subsamples were read with PicoGreen on Days 0, 1, 3, 6, 10 , and 14 . dsDNA standards with $2 \%$ formalin were prepared fresh each day using the MOPS buffer.

\section{RESULTS}

There was a significant $(p<0.05)$ correlation between PFU and bacterial abundance in all of our bioassay incubations (Figs 1 \& 2). In lakes Owasso and Mitchell, PFU and bacterial abundance increased in both incubations with and without nutrients added. The $\mathrm{R}^{2}$ for PFU and bacterial abundance was high in lakes Owasso and Mitchell (Fig. 2; $\mathrm{R}^{2}=0.95$ and 0.98,
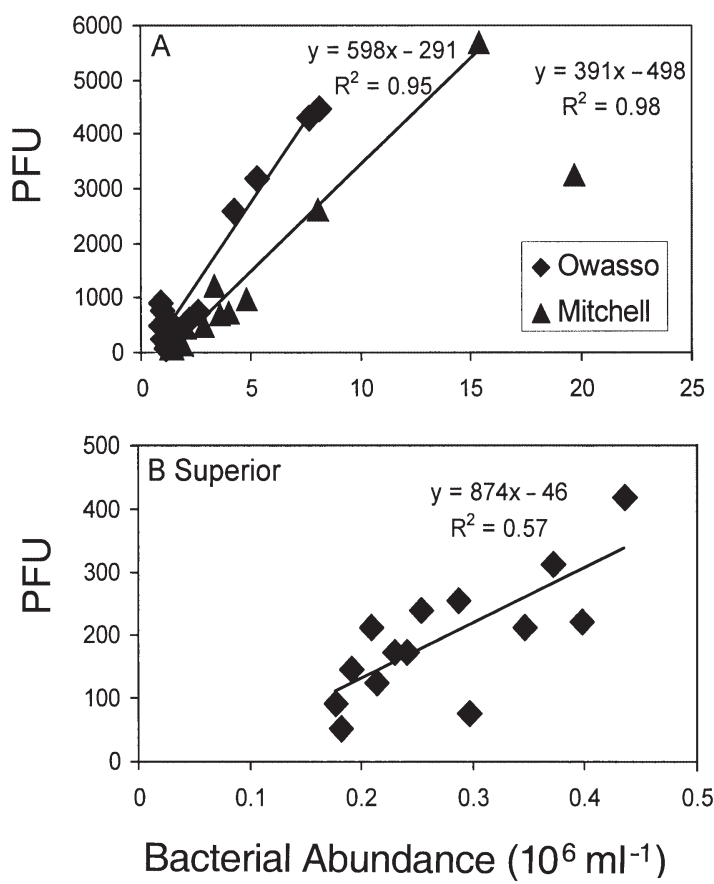

Fig. 2. Regressions of PicoGreen fluorescence (in PFU) against bacterial abundance in dilution cultures for lakes (A) Owasso and Mitchell, and (B) Lake Superior Stns F and G. One outlier in Lake Mitchell was not included in the regression analysis 

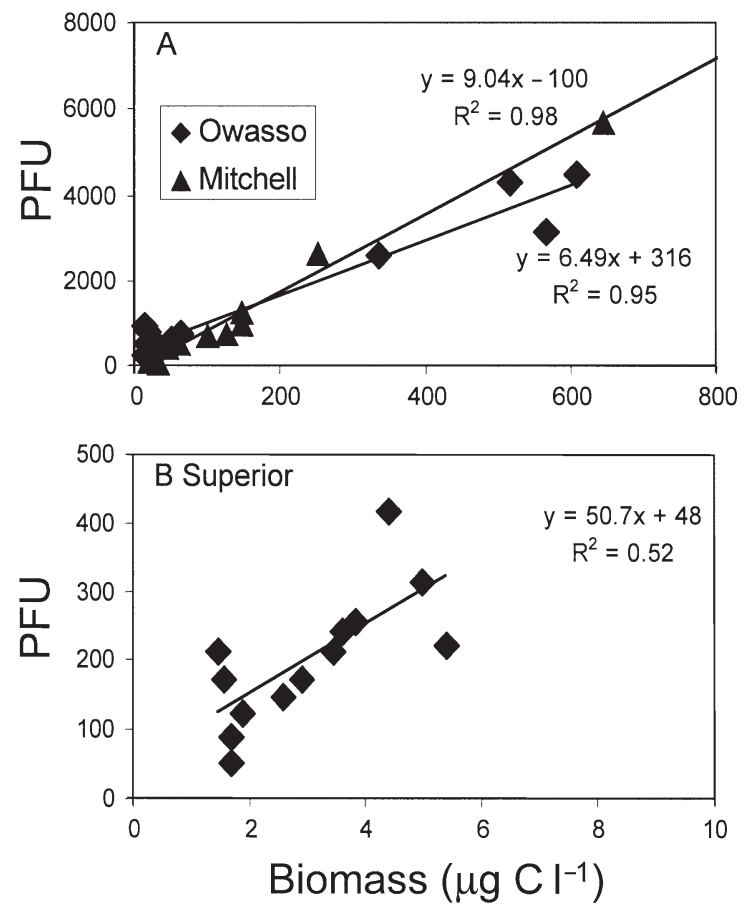

Fig. 3. Regressions of PicoGreen fluorescence (in PFU) against bacterial biomass in dilution cultures for lakes (A) Owasso and Mitchell, and (B) Lake Superior Stns F and G ( $\mathrm{n}=$ 3). One outlier in Lake Mitchell was not included in the regression analysis mass growth rates were significantly higher $(p>0.05)$ than direct counts estimates. The higher growth rate estimates with PicoGreen and biomass estimates probably reflect the fact that both of these measures incorporate information about both the abundance and size of bacteria, whereas the direct counts incorporate only information on abundance. There was a great deal of variability in all of the growth rate estimates, especially in Lake Owasso. There was a tendency for the PFU estimates to be higher in Lake Superior than estimates determined by the other 2 methods (Fig. 4).

Growth rate estimates increased in lakes Owasso and Mitchell with nutrient additions. Growth rate estimates from direct counts in Lake Owasso varied from ca $0.8 \mathrm{~d}^{-1}$ in unamended treatments to $4.1 \mathrm{~d}^{-1}$ in the nutrient broth treatment. In Lake Mitchell, growth rates varied from ca $1.0 \mathrm{~d}^{-1}$ in the unamended treatments to $3.1 \mathrm{~d}^{-1}$ in the nutrient broth treatment.

We used fluorescence data from the dilution cultures to estimate dsDNA content of bacteria in dilution cultures (Fig. 5). The mean dsDNA content of bacteria in Lake Owasso without nutrients added was $3.45 \mathrm{fg}$ cell $^{-1}$ and increased to 3.66 and $6.19 \mathrm{fg} \mathrm{cell}^{-1}$ in the plus nutrient and nutrient broth treatments, respectively. In Lake Mitchell, the mean bacterial dsDNA content was $2.61 \mathrm{fg} \mathrm{cell}^{-1}$ without added nutrients, $3.65 \mathrm{fg} \mathrm{cell}^{-1}$ in the plus nutrient treatment, and $5.05 \mathrm{fg} \mathrm{cell}^{-1}$ in the nutrient broth treatment (Fig. 5). Total DNA content was much lower in Lake Superior cultures (0.6 to 1.81 fg cell $^{-1}$; Fig. 5). The total dsDNA content in the dilu- respectively). In Lake Superior, however, growth rates were substantially lower and more variable. At Stn F, PFU tracked abundance with time $\left(R^{2}=0.57 ; p<0.05\right)$, similar to the other 2 lakes, but at Stn $G$, there was little correlation between abundance and PFU (data not shown).

There was also a strong relation in dilution cultures from these lakes between PFU and biomass (Fig. 3; $\mathrm{R}^{2}=0.95$ and 0.98 for lakes Owasso and Mitchell, respectively). However, in Lake Superior, there was a weak correlation of PFU with biomass $\left(\mathrm{R}^{2}=0.52\right)$ that was, nonetheless, significant $(\mathrm{p}<0.05)$.

We compared growth rate estimates from the microplate reader with direct counts (Fig. 4). Growth rate estimates from $\mathrm{PFU}$ were not significantly different (paired $t$-test; $\mathrm{p}>0.05$ ) from biomass growth rate estimates, but both PFU and bio-

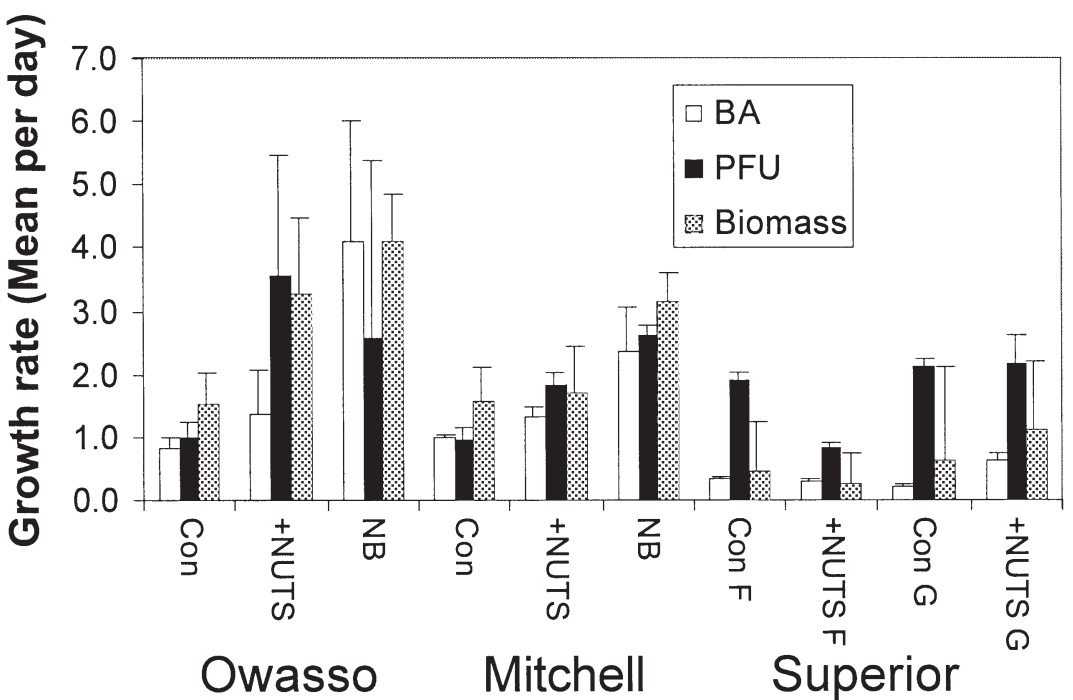

Fig. 4. Mean growth rates $\left(\mathrm{d}^{-1}\right)$ measured in bioassays from direct counts (BA) and PicoGreen fluorescence in (PFU) in lakes Owasso, Mitchell, and Superior. Lakes Owasso and Mitchell had no nutrients added (Con), defined nutrients added (+NUTS; organic carbon as glucose, ammonium, and phosphate), or nutrient broth added $(+\mathrm{NB})$. In Lake Superior, either no nutrients (Con) or defined nutrients were added (+NUTS; organic carbon as glucose, ammonium, and phosphate) at Stns F and G. Each growth rate was estimated from 2 to 5 points during exponential growth. Error bars represent 1 SEM ( $n=2$ to 5 ) 


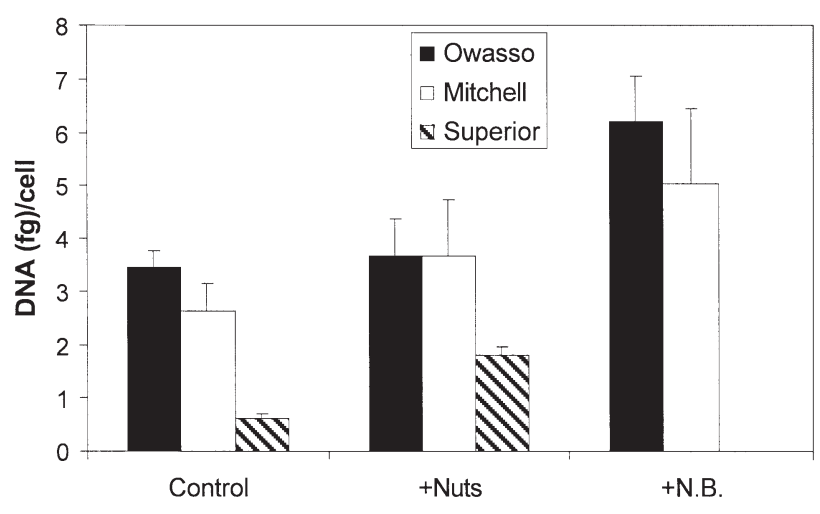

Fig. 5. Double-stranded DNA content in bacterial bioassays in lakes Owasso, Mitchell, and Superior. Data represent means plus 1 SEM ( $n=7$ to 8$)$. The treatments were control (no nutrients), added defined nutrients (+Nuts), and added nutrient broth (+N.B.). No nutrient broth was added to Lake Superior samples

tion cultures increased most in dilution cultures where bacterial biomass also increased, i.e., dilution cultures with added nutrients in lakes Owasso and Mitchell (Fig. 6).

In the $100 \mu \mathrm{l}$ nanocosms, there was a large increase in PFU from $\mathrm{t}=0$ to $\mathrm{t}=48 \mathrm{~h}$ in the 2 eutrophic lakes. There was a significant $\left(\mathrm{p}<0.05 ; \mathrm{R}^{2}=0.70\right.$ ) relation between PFU in bottle cultures and PFU in nanocosms in these dilution cultures (Fig. 7). The slope of the relation was not significantly different from 1 ( $p>0.05)$, indicating that the nanocosms were not biased to higher or lower measurements than the 11 bottle incubations.

To determine whether PicoGreen dsDNA fluorescence could be used reliably to estimate bacterial abundance or biomass in lake water without first filtering it through a $1 \mu \mathrm{m}$ filter to remove non-bacterial seston, we diluted Owasso whole lake water and water that passed a $1 \mu \mathrm{m}$ pore-size filter with $0.2 \mu \mathrm{m}$ filtered water (Fig. 8). There was a strong correlation between PFU and the fraction of both whole lake water and $<1 \mu \mathrm{m}$ filtered lake water diluted with particle-free lake water $\left(R^{2}=0.94\right.$ for whole lake water and $R^{2}=0.98$ for $<1 \mu \mathrm{m}$ filtered lake water). However, there was much more fluorescence in the unfiltered lake water than in the $<1 \mu \mathrm{m}$ treatment, suggesting that most of the particulate dsDNA was in non-bacterial particles in this eutrophic system. Only $26 \%$ of the whole lake water fluorescence was due to particles $<1 \mu \mathrm{m}$ in this lake. A similar fractionation study in Lake Superior showed that there was no detectable difference between whole lake water and $<1 \mu \mathrm{m}$ filtered water in dsDNA content, suggesting that most of the DNA was in the bacterial size fraction (Fig. 8).

Consistent with dilution culture growth rate estimates and the correlation of PFU with biomass, there was a significant $(\mathrm{p}<0.05)$ correlation of bacterial cell size with PFU (Fig. 9). This observation showed that larger cells fluoresce more than smaller cells and that PFU tracked biomass in our incubations.

We measured the size of individual cells in all 3 lakes and all 3 treatments (control, + nutrients, and + nutrient broth). The mean size of bacteria in lakes Owasso and Mitchell was nearly 3 times that of bacteria in Lake Superior. The mean size in Lake Superior was only $11 \mathrm{fg} \mathrm{cell}^{-1}(\mathrm{SE}=0.5)$, whereas the mean size of bacteria in lakes Owasso and Mitchell was 36 (SE = 8) and $31(\mathrm{SE}=4) \mathrm{fg} \mathrm{cell}^{-1}$, respectively.
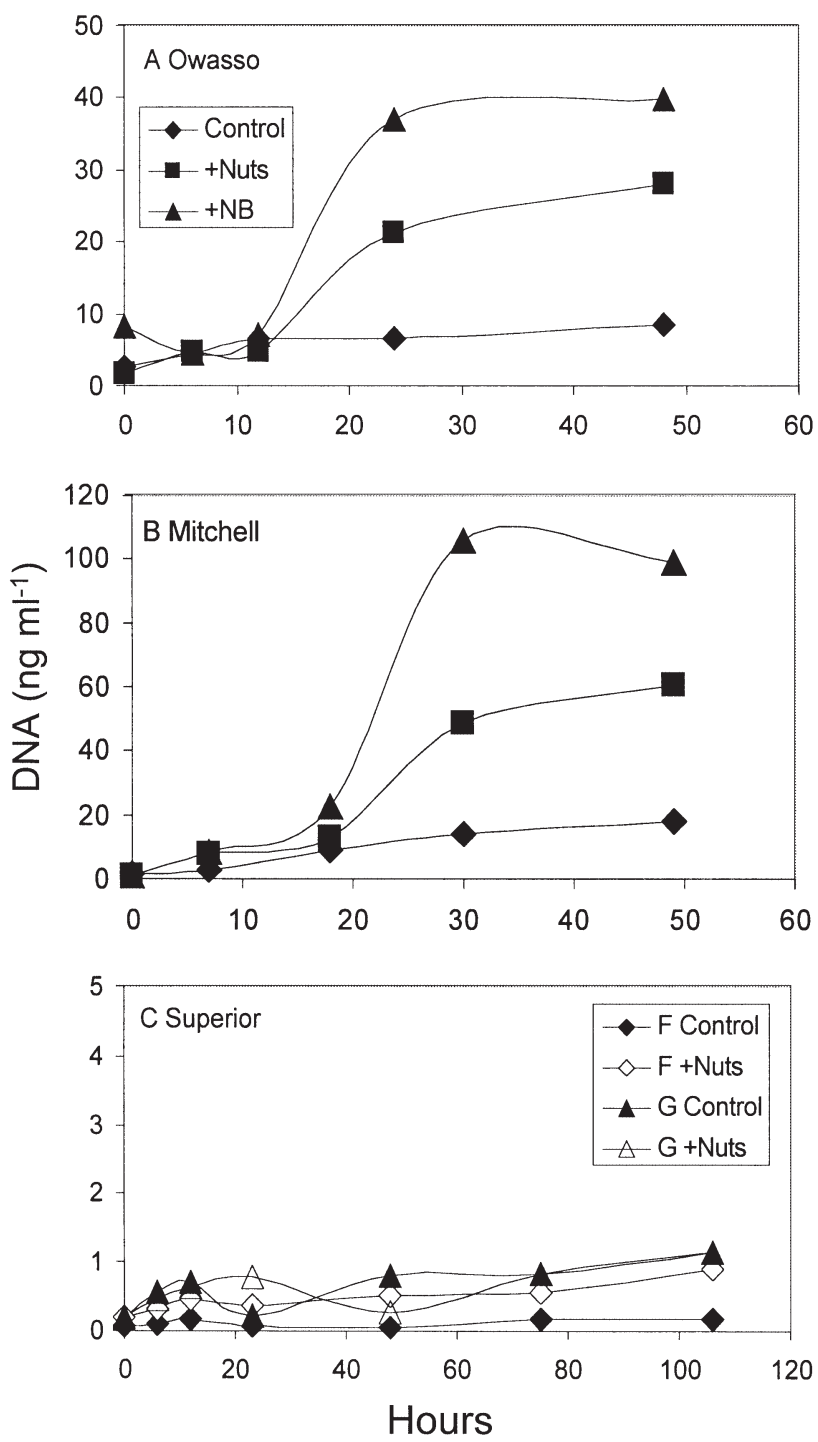

Fig. 6. Time-course of double-stranded DNA concentrations in lakes (A) Owasso, (B) Mitchell, and (C) Superior. Data are shown for control (no nutrient addition), added defined nutrients (+ Nuts) and nutrient broth addition (+NB). Two stations ( $F$ and $G$ ) were sampled in Lake Superior and no nutrient broth was added 


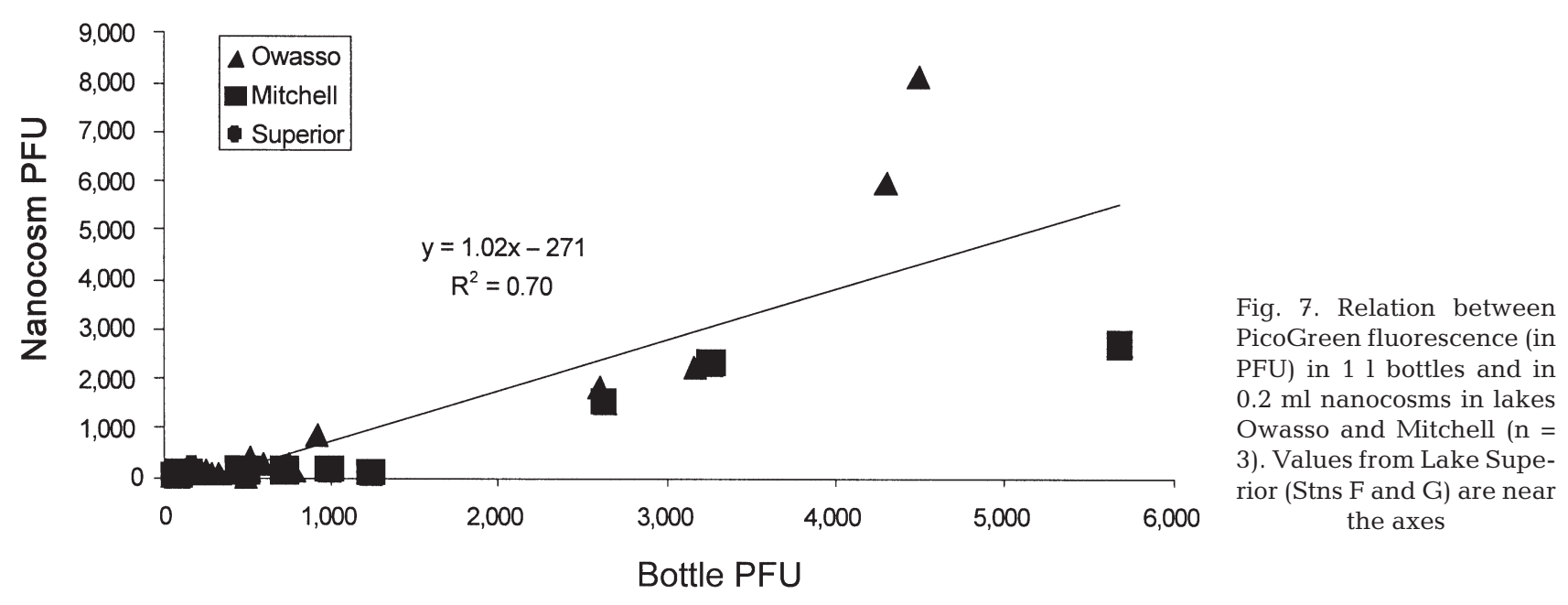

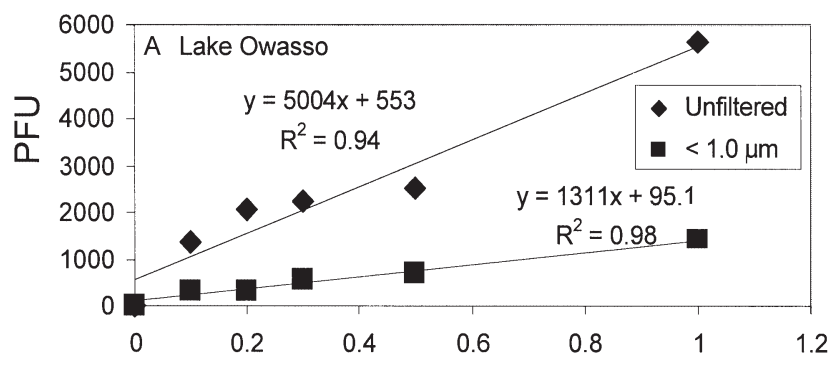

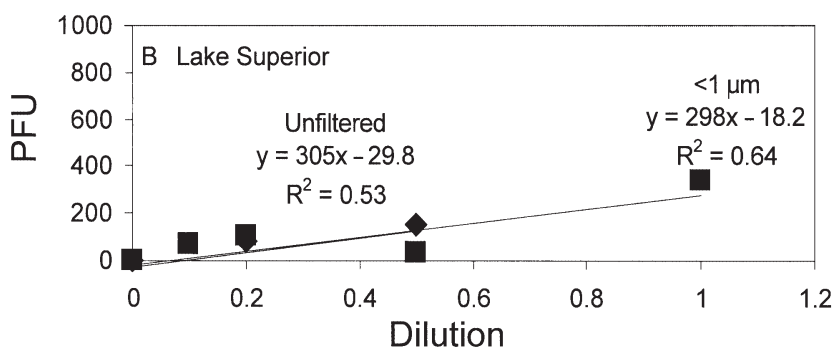

Fig. 8. Size fractionation and dilution of (A) Lake Owasso and (B) Lake Superior water with particle-free $(0.2 \mu \mathrm{m}$ filtered) lake water. Lake water was either unfiltered or filtered through a $1 \mu \mathrm{m}$ pore-size Nuclepore filter and subsequentlydiluted with various quantities of particle-free water $(n=3)$

It would be convenient for conducting PicoGreen growth bioassays if samples could be preserved for several days before analysis in the microplate reader. Bioassays could be conducted without having to transport the microplate reader into the field for rapid measurements. To determine whether preserved samples lose fluorescence with increased preservation time, we added formalin to an Escherichia coli culture and analyzed the dsDNA content for a $2 \mathrm{wk}$ period (Fig. 10). Our data showed that there was an initial decrease of dsDNA content of ca 10 to $15 \%$ relative to the initial content. However, there was no additional change in the dsDNA content after the initial decrease.

\section{DISCUSSION}

One of the revelations of the past $20 \mathrm{yr}$ was the important role that heterotrophic bacteria play in food web structure and function (Porter 1996) as well as biogeochemical processes (del Giorgio et al. 1997) in marine and freshwater ecosystems. Furthermore, there is considerable evidence that bacterioplankton can be limited by inorganic as well as organic nutrient availability in both freshwater and marine systems (Toolan et al. 1991, Coveney \& Wetzel 1992, Pomeroy et al. 1995, Tortell et al. 1996, Cotner et al. 1997).

Tranvik (1997) showed the utility of the dsDNA stain PicoGreen to examine bacterial abundance in aquatic systems rapidly and effectively. Our measurements

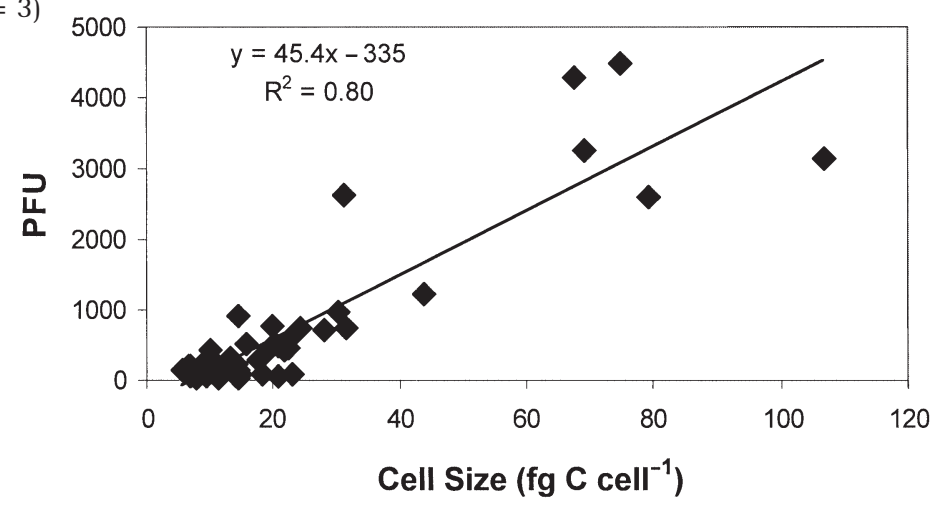

Fig. 9. Relation between cell size and PicoGreen fluorescence (in PFU) in dilution cultures from lakes Owasso, Mitchell, and Superior 
show that this method can be used for measuring bacterial abundance, especially in productive ecosystems, such as lakes Owasso and Mitchell. Our experiments also showed that PicoGreen is an effective stain for measuring biomass changes in dilution cultures and, when used with a microplate reader, it can save many hours of preparation and analysis time. Our results contrast somewhat with those of Tranvik (1997), who found no correlation of cell-size and cell-specific fluorescence. We found that larger cells did fluoresce more intensely than smaller cells (Fig. 9). The fact that we performed our assays in dilution cultures and in 2 eutrophic lakes may explain some of these differences. Cells that grow rapidly are typically larger than slower growing cells (see below) and cells tend to be larger when there are no bacterivores present (Cole et al. 1993). Despite the simplicity and utility of this method, it is not a substitute for measuring in situ bacterial production, as commonly measured with ${ }^{3} \mathrm{H}$-labelled leucine or thymidine (Kirchman 1993), because of the long incubation times and removal of bacterial competitors and predators in dilution cultures. Its greatest utility is likely to be in conducting limiting nutrient or other types of bioassays.

PicoGreen has many characteristics that make it particularly useful for quantifying bacterial dsDNA in aquatic systems. Unlike the Hoechst family of stains, it does not require UV excitation and is extremely sensitive. Background fluorescence is relatively low and the signal is enhanced when the stain binds to dsDNA, which is important when measurements are made in solution. Once the stain has been added to the samples, the readings are very stable for 15 to $20 \mathrm{~min}$. Other dsDNA stains with high fluorescence yields such as TOTO, TO-PRO, YOYO, and YO-PRO have been used to quantify bacterial DNA in aquatic systems using flow cytometry (Li et al. 1995, Marie et al. 1996) but high background fluorescence can complicate measurements in solution. Marie et al. (1996) compared the utility of YOYO-1, YO-PRO-1, and PicoGreen for counting bacteria using flow cytometry and found optimal results with YOYO-1 and PicoGreen. The selectivity of PicoGreen for dsDNA over singlestranded DNA greatly increases the capability of using it to quantify particulate DNA associated with planktonic organisms, despite the presence of high concentrations of dissolved DNA, which can be significant (Jørgensen et al. 1993). Molecular Probes' product literature lists the sensitivity of the PicoGreen assay at $25 \mathrm{pg}$ dsDNA ml ${ }^{-1}$ and Hoechst, YO-PRO, and YOYO stains at $500 \mathrm{pg} \mathrm{ml}^{-1}$ or greater. The bioassays that we conducted in lakes Owasso and Mitchell were initiated at levels well above this detection limit (ca 1 to $2 \mathrm{ng}$ $\mathrm{ml}^{-1}$ ) and increased to as much as $99 \mathrm{ng} \mathrm{ml}^{-1}$, but in Lake Superior initial values were near this detection

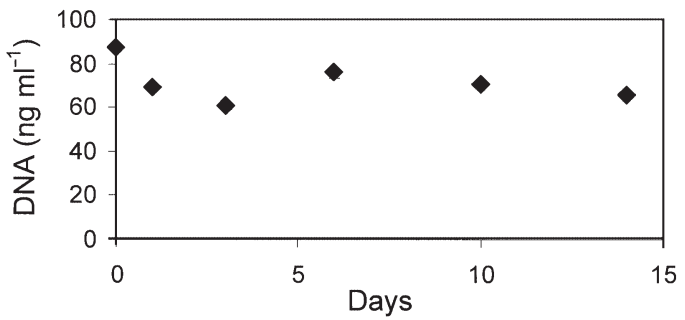

Fig. 10. Measured bacterial DNA in an Escherichia coli culture that was preserved for various lengths of time before running the PicoGreen assay. The culture was grown overnight and preserved to $2 \%$ final concentration with formalin, and the PicoGreen assay was conducted after 0, 1, 3, 6, and $10 \mathrm{~d}$. Error bars (SE) are smaller than the size of the points on the figure $(\mathrm{n}=3)$

limit and never increased above $1.2 \mathrm{ng} \mathrm{ml}^{-1}$, perhaps complicating measurements in that system (Fig. 5).

What are the disadvantages of the method? Microplate readers cost about double that of a good fluorometer but are far less expensive than a flow cytometer. Perhaps the most important shortcoming was the relatively low sensitivity of the method for measuring bacterial growth rates in extremely low productivity systems like Lake Superior. Although we found significant correlation of bacterial abundance and biomass with PFU in Lake Superior, the relation was not nearly as strong as it was in the eutrophic systems where we also made these measurements. Low growth rates, small bacterial cell size, and low DNA content (Fig. 5) all limit an investigator's ability to use this bioassay method in highly oligotrophic systems such as Lake Superior. In Lake Superior, we have been more successful using RiboGreen (Molecular Probes), which stains both double-stranded and singlestranded nucleic acids, for measuring bacterial nucleic acid content (data not shown).

Another limitation is that dilution cultures are not 'instantaneous' measurements. Our dilution cultures were incubated for 2 to $4 \mathrm{~d}$. Many artifacts can be introduced into growth assays when experiments are conducted over such a long period (Sherr et al. 1999). In a study comparing bacterial activity in incubation experiments with activity in situ, cell-specific rates increased nearly an order of magnitude over a ca $1 \mathrm{~d}$ incubation period (Sherr et al. 1999). Nonetheless, in many cases, dilution cultures have the advantage that they measure net production rather than gross production, as is typically the case in isotope assays. Furthermore, in many cases, dilution cultures may be preferred to isotope assays because they integrate production over a longer period. For instance, in our laboratory, we measure bacterial respiration rates and calculate bacterial growth efficiency as the quotient of bacterial production over the sum of bacterial produc- 
tion plus bacterial respiration (Biddanda et al. 2001). Instantaneous production measurements over the course of the 2 to $3 \mathrm{~d}$ incubations typically required to measure respiration rates can vary by an order of magnitude or more. It is often ambiguous whether one should use the initial growth rate, an average growth rate, or an integration of individual growth rate measurements. In this case, the dilution culture method automatically provides that integrated measurement.

Viral dsDNA may complicate bacterial dilution culture bioassays. Presumably some of the signal observed in our cultures may be due to virus particles. Uncorrected blanks that have been filtered through a $0.2 \mu \mathrm{m}$ filter are typically about 8000 to $10000 \mathrm{PFU}$, suggesting some dsDNA or some other interference in this small size fraction. However, little dissolved DNA in marine systems is viral (Jiang \& Paul 1995) and some of the viral DNA is single stranded. Our data (Fig. 9) indicated that fluorescence is proportional to bacterial biomass, suggesting that small viral particles would contribute little to the total signal.

One of the issues that we addressed in this study is whether growth assays could be conducted in the microplate wells, i.e., nanocosms, rather than in large bottles. The advantages of this kind of bioassay are potentially huge. It minimizes the amount of water that needs to be filtered because the assay volume required is so small. Bioassays used to examine the effects of 3 different nutrients (e.g., control, organic carbon, inorganic nitrogen, and phosphorus, for instance) in triplicate 11 bottles require ca $12 \mathrm{l}$ of $0.2 \mu \mathrm{m}$ filtered lake or seawater and 1.21 of 0.8 or $1 \mu \mathrm{m}$ filtered water. A similar bioassay conducted in microplates requires less than $10 \mathrm{ml}$. Small sample volume in the microplate requires correspondingly low quantities of the relatively expensive fluorochrome. A further advantage is the reduced space that is required to incubate microplates rather than polycarbonate bottles. Factorialdesigned nutrient addition bioassays on a microplate reader may be conducted in an extremely small amount of space in an incubator.

In our comparison of nanocosm assays with bottle assays, we found a strong correlation in the eutrophic lakes (Fig. 7; $\mathrm{R}^{2}=0.70$ ). In these eutrophic systems, with rapid growth rates, there apparently was little negative effect of conducting assays in such small volumes. The fact that the slope of the regression of fluorescence in bottles versus fluorescence in microplate wells was very nearly 1.0 indicated that the nanocosms did not significantly overestimate or underestimate bacterial biomass in these lakes. However, nanocosms were not effective in the oligotrophic Lake Superior cultures. One reason why nanocosms may not be as effective at measuring growth rates in oligotrophic systems is that the long incubations required to measure growth also increase the amount of time available for artifacts (such as growth on walls) to complicate measurements.

PicoGreen should not be used in most systems to measure ambient bacterial biomass without filtration because a large fraction of the dsDNA is not bacterial, especially in eutrophic lakes (Fig. 8). In Lake Owasso, whole lake water contained ca $42 \mu \mathrm{g}$ DNA $1^{-1}$ and the bacterial size-fraction contained only $11 \mu \mathrm{g}$ DNA $\mathrm{l}^{-1}$. However, in Lake Superior most of the dsDNA was in bacterial-sized particles and, therefore, it may be expedient to omit the filtration step in this and other unproductive lakes. Pre-filtration can be used to remove most, if not all, of the non-bacterial biomass, but one should be cautious that bacteria are not removed in the pre-filtration step, as well.

In our study, the differences in percentage bacterial dsDNA between lakes Owasso and Superior probably reflect differences in the percentage bacterial biomass in the 2 systems (Biddanda et al. 2001, Cotner \& Biddanda unpubl. data). Previous work in Lake Owasso showed that bacteria $(<1 \mu \mathrm{m}$ size fraction) comprised 15 to $31 \%$ of the total sestonic organic carbon and in Lake Superior they comprised 46 to $59 \%$ (Biddanda et al. 2001), consistent with the relative DNA content reported here. The bacterial dsDNA content measured in lakes Owasso, Mitchell, and Superior varied from 0.6 to $6.2 \mathrm{fg} \mathrm{cell}^{-1}$ in the various nutrient treatments and controls (Fig. 5), similar to values that have been measured in other systems. Bacteria typically contain anywhere from 0.5 to $20 \mathrm{fg}$ of DNA cell ${ }^{-1}$ and it constitutes ca 3 to $9 \%$ of cell $D W$ in an average cell (Neidhardt et al. 1990). We estimated the carbon content of bacteria in the 3 systems we studied at 11 to $36 \mathrm{fg}$ cell $^{-1}$. Therefore, bacteria in Lake Owasso were about $5 \%$ dsDNA and those in lakes Mitchell and Superior were ca $3 \%$ dsDNA by weight.

Others have found similar dsDNA content in aquatic bacteria. Tranvik (1997) found a strong correlation $\left(\mathrm{R}^{2}=0.93\right)$ between bacterial abundance and dsDNA measured with PicoGreen, and the slope suggested a bacterial DNA content of ca $6 \mathrm{fg} \mathrm{cell}^{-1}$. In Resurrection Bay, Alaska the DNA content of bacteria was less than one-third of that of a starved Pseudomonad culture (Robertson \& Button 1989). In the northern Gulf of Mexico, bacterial DNA content measured with thiazole orange was $5.8 \mathrm{fg} \mathrm{cell}^{-1}$ (Jeffrey et al. 1996). Also, the average bacterial DNA content in estuarine, coastal, and oligotrophic oceanic environments off the southwest coast of Florida was $5.7 \mathrm{fg} \mathrm{cell}^{-1}$ (Paul et al. 1985). In this study and another (DeFlaun et al. 1986) where bacterial DNA content in marine systems was measured with Hoechst 33258, bacterial DNA content increased in the most productive ecosystems. However, the proportion of particulate DNA in bacteria 
relative to other components of the water column actually decreased in the most eutrophic systems (Paul et al. 1985, DeFlaun et al. 1986). One study where bacterial DNA was measured across a marine trophic gradient showed that the $<0.8 \mu \mathrm{m}$ size fraction represented $90 \%$ of the total particulate DNA in oligotrophic Gulf of Mexico waters but only $20 \%$ in more productive estuaries (Jeffrey et al. 1996), similar to the range we report here for lakes Owasso and Superior.

Our growth rate measurements in all 3 lakes indicated that direct count-inferred rates were lower than those determined by PicoGreen and from image analysis. Biomass-inferred rates were similar to or slightly higher than PicoGreen estimates (Fig. 4). Direct counts would not account for all of the growth in the cultures due to increased bacterial size, whereas the biomass estimates and PicoGreen would. In support of this, in all of the PicoGreen assays that we conducted, the fluorescence cell ${ }^{-1}$ at the end of the $2 \mathrm{~d}$ assay increased relative to the initial value. Also, microscopic observations showed that bacterial size increased with time in our dilution cultures.

Growth rate has important effects on the composition of a bacterial cell. As bacterial growth rates increase, DNA content also increases as a function of an increase in the number of replication forks in the cell (Chesbro et al. 1990). Our data reflect this relation with a higher DNA content cell ${ }^{-1}$ in faster growing cells. In the 3 systems we studied, bacterial dsDNA content was similar and relatively high in lakes Owasso and Mitchell, where bacterial growth rates were most rapid (Fig. 4).

There is promise for using this technique for fine time scale monitoring of microbial responses to substrates or pollutants. The microplate reader can read a 96-well system in less than a minute, greatly enhancing our capability to monitor short-term responses such as lag or growth events in cultures or bioassays. Both the collection of numerous sub-samples at frequent intervals and subsequent epifluorescence enumeration of bacteria in dilution cultures (Ammerman et al. 1984) would be tedious, if not impossible, to carry out. The same task can be done with ease by the use of microplate assays of PicoGreen-stained samples. Both the number of replicates and the frequency of measurement can be increased substantially at little increase in cost or time.

In conclusion, we found that the PicoGreen microplate assay was an effective method for tracking both bacterial biomass and abundance in dilution cultures. The method was most useful in relatively high growth rate systems where artifacts due to incubations are minimized and sensitivity is maximized. In highly oligotrophic lakes, this method has less utility because of the slow growth rates and small bacterial biomass.
In the moderately productive systems that constitute most natural waters of interest, bioassays can be conducted directly in the microplates, increasing potential treatments, minimizing space requirements in incubators, and increasing replication. However, similar experiments should be performed in other systems to confirm these results.

Acknowledgements. This work was partially supported by NSF (DEB-9977047) and NOAA (46290000). We thank the crew of the RV 'Blue Heron' for cruise support and E. Hall, W. Makino, and 2 anonymous reviewers for comments on a previous version of this paper.

\section{LITERATURE CITED}

Ammerman JW, Fuhrman JA, Hagström ^̊, Azam F (1984) Bacterioplankton growth in seawater: I. Growth kinetics and cellular characteristics in seawater cultures. Mar Ecol Prog Ser 18:31-39

Biddanda BA, Ogdahl ML, Cotner JB (2001) Dominance of bacterial metabolism in oligotrophic relative to eutrophic waters. Limnol Oceanogr 46:730-739

Button DK, Robertson BR (1993) Use of high-resolution flow cytometry to determine the activity and distribution of aquatic bacteria. In: Kemp PF, Sherr BF, Sherr EB, Cole JJ (eds) Handbook of methods in aquatic microbial ecology. Lewis, Boca Raton, FL, p 163-173

Chesbro W, Arbige M, Eifert R (1990) When nutrient limitation places bacteria in the domains of slow growth: metabolic, morphologic and cell cycle behavior. FEMS Microbiol Ecol 74:103-120

Cole JJ, Pace ML, Caraco NF, Steinhart GS (1993) Bacterial biomass and cell size distributions in lakes: more and larger cells in anoxic waters. Limnol Oceanogr 38: $1627-1632$

Cotner JB, Ammerman JA, Peele ER, Bentzen E (1997) Phosphorus limited bacterioplankton growth in the Sargasso Sea. Aquat Microb Ecol 13:141-149

Coveney MF, Wetzel RG (1992) Effects of nutrients on specific growth rate of bacterioplankton in oligotrophic lake water cultures. Appl Environ Microbiol 58:150-156

DeFlaun MF, Paul JH, Davis D (1986) Simplified method for dissolved DNA determination in aquatic environments. Appl Environ Microbiol 52:654-659

del Giorgio PA, Cole JJ, Cimbleris A (1997) Respiration rates in bacteria exceed phytoplankton production in unproductive aquatic systems. Nature 385:148-151

El-Shaarawi A, Munawar M (1978) Statistical evaluation of the relationships between phytoplankton biomass, chlorophyll $a$, and primary production in Lake Superior. J Great Lakes Res 4:443-455

Fuhrman JA, Azam F (1982) Thymidine incorporation as a measure of heterotrophic bacterioplankton production in marine surface waters: evaluation and field results. Mar Biol 66:109-120

Hobbie JE, Daley RJ, Jasper S (1977) Use of Nuclepore filters for counting bacteria by fluorescence microscopy. Appl Environ Microbiol 33:1225-1228

Jeffrey WH, Von Haven R, Hoch MP, Coffin RB (1996) Bacterioplankton RNA, DNA, protein content and relationships to rates of thymidine and leucine incorporation. Aquat Microb Ecol 10:87-95 
Jiang SC, Paul JH (1995) Viral contribution to dissolved DNA in the marine environment as determined by differential centrifugation and kingdom probing. Appl Environ Microbiol 61:317-325

Jørgensen NOG, Kroer N, Coffin RB, Yang XH, Lee C (1993) Dissolved free amino acids, combined amino acids, and DNA as sources of carbon and nitrogen to marine bacteria. Mar Ecol Prog Ser 98:135-148

Kirchman DL (1993) Leucine incorporation as a measure of biomass production by heterotrophic bacteria. In: Kemp PF, Sherr BF, Sherr EB, Cole JJ (eds), Handbook of methods in aquatic microbial ecology. Lewis, p 509-512

Kirchman D, K'nees E, Hodson R (1985) Leucine incorporation and its potential as a measure of protein synthesis by bacteria in natural aquatic systems. Appl Environ Microbiol 49:599-607

Li WKW, Jellett JF, Dicki PM (1995) DNA distributions in planktonic bacteria stained with TOTO or TO-PRO. Limnol Oceanogr 40:1485-1495

Loferer-Krössbacher M, Klima J, Psenner R (1998) Determination of bacterial cell dry mass by transmission electron microscopy and densitometric image analysis. Appl Environ Microbiol 64:688-694

Marie D, Vaulot D, Partensky F (1996) Application of the novel nucleic acid dyes YOYO-1, YO-PRO-1, and PicoGreen for flow cytometric analysis of marine prokaryotes. Appl Environ Microbiol 62:1649-1655

Moreiraturcq P, Martin JM, Fleury A (1993) Chemical and biological characterization of particles by flow cytometry in the Krka Estuary, Croatia. Mar Chem 43:115-126

Neidhardt FC, Ingraham JL, Schaechter M (1990) Physiology of the bacterial cell: a molecular approach. Sinauer, Sunderland

Paul JH, Jeffrey WH, Deflaun M (1985) Particulate DNA in sub-tropical oceanic and estuarine planktonic environ-

Editorial responsibility: Robert Sanders,

Philadelphia, Pennsylvania, USA ments. Mar Biol 90:95-102

Pomeroy LR, Sheldon JE, Sheldon WM, Peters F (1995) Limits to growth and respiration of bacterioplankton in the Gulf of Mexico. Mar Ecol Prog Ser 117:259-268

Porter J, Diaper J, Edwards C, Pickup R (1995) Direct measurements of natural planktonic bacterial community viability by flow cytometry. Appl Environ Microbiol 61: 2783-2786

Porter KG (1996) Integrating the microbial loop and the classic food chain into a realistic planktonic food web. In: Polis GA, Winemiller KO (eds), Food webs: integration of patterns and dynamics. Chapman and Hall, New York, p 51-59

Porter KG, Feig YS (1980) The use of DAPI for identifying and counting aquatic microflora. Limnol Oceanogr 25:943-948

Robertson BR, Button DK (1989) Characterizing aquatic bacteria according to population, cell size, and apparent DNA content by flow cytometry. Cytometry 10:70-76

Sherr EB, Sherr BF, Sigmon CT (1999) Activity of marine bacteria under incubated and in situ conditions. Aquat Microb Ecol 20:213-223

Toolan T, Wehr JD, Findlay S (1991) Inorganic phosphorus stimulation of bacterioplankton production in a mesoeutrophic lake. Appl Environ Microbiol 57:2074-2078

Tortell PD, Maldonado MT, Price NM (1996) The role of heterotrophic bacteria in iron-limited ocean ecosystems. Nature 383:330-332

Tranvik LJ (1997) Rapid fluorometric assay of bacterial density in lake water and seawater. Limnol Oceanogr 42: $1629-1634$

Yentsch C, Horan P, Muirhead K, Dortch Q, Haugen E, Legendre L, Murphy L, Perry M, Phinney D, Pomponi S, Spinrad R, Wood M (1983) Flow cytometry and cell sorting: a technique for analysis and sorting of aquatic particles. Limnol Oceanogr 28:1275-1280

Submitted: October 25, 2000; Accepted: June 1, 2001

Proofs received from author(s): July 24, 2001 